\title{
6 Masculinity at Work: Intersectionality and Identity Constructions of Migrant Domestic Workers in the Netherlands
}

\author{
Aster Georgo Haile ${ }^{1}$ and Karin Astrid Siegmann ${ }^{2}$
}

\begin{abstract}
$^{3}$
This chapter contributes to the emerging literature on men who do 'women's work'. It focuses on the 'feminine' occupation of domestic worker and on how male and female migrant workers balance their gender identities at the intersection of class, race, and immigration status. It addresses the related research gap in the Netherlands by focusing on the situation of migrant domestic workers from the Philippines with irregular status. From the perspective of hegemonic gender identities, male migrant domestic workers, too, are subjected to gender injustices. These injustices are rooted in the devaluation of everything coded as 'feminine', including their occupation. The resulting 'male femininities' are threatening male domestic workers' sense of self-worth and their societal recognition. This misrecognition adds to the exploitative economic circumstances that both female and male migrant domestic workers experience and has negative repercussions on male migrants' access to employment. Ironically, workers themselves contribute to reproducing these symbolic and material injustices and, hence, consolidate them. Redressing these injustices requires changes both in the economic structure and in society's ordering of status. When the demands for respect for domestic workers and for their labour rights are combined, this necessity is reflected in workers' national and international campaigns. They need to be complemented by national regulation that will protect all workers effectively, independent of the location of their work, their gender, their race, or their immigration status. Last but not least, given their crucial role in societal reproduction, domestic workers should be included in the categories of migrant workers who are welcome in European labour markets in redefined and relaxed transnational migration regimes.
\end{abstract}

Keywords: domestic work, gender hegemony, gender identity, gender justice, intersectionality, the Netherlands, the Philippines, migrants with irregular status.

\subsection{Introduction}

During the twentieth century, domestic work ${ }^{4}$ was seen as an anachronism in an industrial society. This occupation was assumed to vanish in the course of

1 Aster Georgo Haile, graduate student at the Africana Studies Department, University at Albany, State University of New York. She conducted the empirical research for this chapter in the context of her MA thesis at the International Institute of Social Studies (ISS) of Erasmus University Rotterdam, see Haile (20II).

2 Karin Astrid Siegmann, Senior Lecturer in Labour and Gender Economics, International Institute of Social Studies (ISS) of Erasmus University Rotterdam (corresponding author). modernization (King 2007: 48; Bartolomei, 20I0: 88). Yet even in the industrialized societies of Europe and North America, domestic work still has a significant role to play and is even increasing (ILO 20IO: 6). This

3 The authors are indebted to the women and men who shared their stories. Thoughtful comments and suggestions by two anonymous referees are gratefully acknowledged. They helped to significantly improve the chapter. All remaining errors are solely ours.

4 In spite of the heterogeneity of tasks performed by domestic workers - cleaning, looking after elderly people or children, guarding the house, driving children to school, gardening, cooking -, a feature common to all workers is that they work for a private household (Simonovsky/Luebker 20II: 2). 
growth in paid domestic labour has been debated as part of the commoditization and internationalization of social reproduction. The debate has raised questions regarding domestic workers' position in the labour market as well as the forms of injustice they face individually and collectively, particularly their effective access to social rights. The growth in paid domestic labour has also been shown to pose challenges to the gender identities of migrant domestic workers who are over-represented amongst those who fill the gap in reproductive work (e.g. Kilkey 20IO: I32-I33; Moya 2007; Sarti 2006: 23I). The literature on 'global care chains' has highlighted that, for many female migrant domestic workers, leaving behind their children undermines their ability to fulfil their idealized role as carers (Hochschild 2000; Lan 2003; Yeates 2004). This debate has ignored the situation of male migrants employed in domestic service (Kilkey 20I0: I28). An emerging strand of literature points out that men, too, struggle to combine their work in a feminized occupation with hegemonic masculinities (e.g. Bartolomei 20I0; Datta/McIlwaine/Herbert/Evans/ May/Wills 2009; Donaldson/Howson 2009; Herbert 2008). Yet the asymmetrical relationship of hegemonic masculinity and femininity has often dropped out of focus in studies on gender identity (Connell/ Messerschmidt 2005: 848), including those concentrating on domestic workers. By and large, they have focused either on female or - rarely - male gender identities. This relationship is crucial, though, for analysing the reproduction of gender inequalities as a process that intersects with other systems of discrimination.

This chapter explores the related experience of Filipino men and Filipina women ${ }^{5}$ with irregular immigration status ${ }^{6}$ who engage in domestic work in the Netherlands. Research on migrant domestic workers from the Philippines has focused on women (e.g. Asis/Huang/Yeoh 2004; Chang/Ling 2000; Hochschild 2000; Parreñas 2005). Far less work has been done on the experiences of their male colleagues, despite the fact that they form a significant group amongst migrant domestic workers in various European countries (e.g. Sarti 20I0: 29-30). While the situ-

5 In the following, the adjective 'Filipina' is employed to refer to women from the Philippines, while 'Filipino' denotes men from the same country of origin.

6 Following UNESCO (2008: 15), "persons with irregular immigration status" refers to persons "entering, travelling through or residing in a country without the necessary documents or permits". ation of migrant domestic workers in other European countries has been addressed in detailed studies (e.g. León 20IO; Lutz 2008; Sarti 20IO), little research has covered the situation in the Netherlands. The few existing studies largely take the perspective of employers (de Ruijter 2004; de Ruijter/van der Lippe 2009) or focus on the situation of female domestic workers (van Dijken 2002; Koo 20II; Marchetti 2005, 20IO). ${ }^{7}$

The present chapter addresses two questions, namely: How do Filipino domestic workers in the Netherlands balance their sense of masculinity with doing work that is widely perceived as 'feminine'? And how do male and female migrant domestic workers with irregular status from the Philippines express their gender identity at the intersection of different relations of power, such as class, race, and immigration status? The chapter contrasts the construction of, and challenges for, male Filipino migrant domestic workers' gender identity with those of their female colleagues, while acknowledging the refraction of the resulting gender injustices through the prism of other social divisions. The chapter adopts Fraser's (2007) approach to gender justice that sees the gendered character of the political economy as inextricably interwoven with the cultural order. A full understanding of gender justice hence becomes available only if material reward and social recognition are considered simultaneously (Fraser 2007: 25).

Section 6.2 outlines the concept of hegemonic gender identities and their intersection with other social divisions. The specific contours of this hegemony for migrant workers from the Philippines are then sketched out. Section 6.3 reviews previous research that has applied the concept of gender as intersectionality to the study of domestic workers' identity constructions. Section 6.4 presents the sociopolitical context of the Netherlands that forms the stage for the present investigation, while section 6.5 describes its research methodology. Findings related to gender identity constructions of Filipina/o migrant domestic workers in the Netherlands and their intersections with class, race, and (irregular) immigration status are presented and discussed in sections 6.6 and 6.7. They are placed in the context of gender justice in the concluding section.

7 Botman (2OII) and van Walsum (2OII) are exceptions here. 


\subsection{Hegemonic Gender Identities - Concept and Context}

Femininity and masculinity are cultural ideal types of how women and men ought to be. Yet idealized features of masculinity and femininity as complementary and hierarchical gender identities also provide a rationale for social relations at all levels, from the self to global relations of domination. It is through social practice, including both behaviour and discourse, that this hierarchical relationship organizes the material relations of social life and (re-)produces gender inequalities (Schippers 2007: 9I-92, I00). Hegemonic masculinity is hierarchical and complementary in that it legitimates men's dominance over women as a group (Schippers 2007: 87). While not necessarily normal in a statistical sense, it is normative, embodying the most honoured way of being a man (Connell/Messerschmidt 2005: 832). The concept of hegemonic masculinity intersects with class and race in its conflation with middle-class status and whiteness, turning gender practices of subordinated classes and/or racialethnic ${ }^{8}$ men into 'male femininities' as "the characteristics and practices that are culturally ascribed to women" (Schippers 2007: 96). They threaten the hierarchical relationship between masculinity and femininity. As a result, "they are both feminising and stigmatising to the men who embody them" (Schippers 2007: 96). Yet their intersection with class also implies that features of hegemonic masculinities may be adjusted to economic necessities. Gutmann (I996, quoted in Schippers 2007: 97) demonstrates the intersection of gender identity with class for notions of fathering in Mexico. There, for lower-class families, economic changes have necessitated men's participation in childcare, leading to ideological changes in the meanings of fatherhood and its centrality for defining manliness. Rather than being self-reproducing, Connell and Messerschmidt (2005: 844) stress that hegemonic masculinity requires the policing of men as well as the exclusion or discrediting of women. Yet women's practices that comply with and hence reproduce patriarchy, enacting the qualities bundled in the concept of hegemonic femininity (Schippers 2007: 94), are central to many of the processes that construct masculinities, for instance as wives and as work-

8 Following Nakano Glenn (1992: 41), Duffy (2007: 333) employs this term to refer to "groups that have been socially constructed and constituted as racially as well as culturally distinct from European Americans”. ers in the gender division of labour (Connell/Messerschmidt 2005: 848).

In the contemporary Philippines, from which this study's respondents originate, hegemonic masculinity of urban middle-class men refers to a breadwinner father, while the ideal femininity relates to a caring, nurturing mother. Women can have jobs, but not careers, because of the constraint of domestic responsibilities (Medina 200I, quoted in Parreñas 2005: 33I). Gender identities are closely related to the ideal of the nuclear, heterosexual family as the social institution in the Philippines commanding the most loyalty, sacrifice, and affection (Asis/Huang/Yeoh 2004: 202). Explained as one of the consequences of Spanish and US colonization of the Philippines, these ideals form the background for the emergence of the 'woman family hero'. She is a construct that depicts the female migrant who makes sacrifices and dramatic choices in order to take responsibility for maintaining and improving her family's lifestyle as well as contributing to her country's economy (Marchetti 2005: 35).

\subsection{Domestic Work and the Production of Migrant Identities}

Historically, a high proportion of migrant workers has characterized domestic service (Moya 2007). During the last three decades, paid domestic work has emerged as an often unique employment opportunity for transnational migrant women in most industrialized countries (Marchetti 20IO: I22; Sarti 20IO: 25). The emergence of such 'global care chains' has been attributed, amongst other reasons, to the lack of attention paid to care policy in industrialized countries, which catalyses the demand for private solutions (ILO 20I0: 9). Sarti (20I0: 25) summarizes crucial demand factors when she writes that: "[ $t]$ hanks to immigrants, the supply of staff has become cheap and abundant".

Despite the economic significance of the occupation, domestic work has often not been recognized as real work and hence has been undervalued and poorly regulated (ILO 20IO; Luebker/Simonovsky/Oelz 20II; Oelz 20II). This lack of recognition and reward has been explained by reference to gender constructions of the occupation. It has frequently been perceived as an extension of unpaid female domestic responsibilities in the home (King 2007: 47; Ray 2000: 693). For Italy, Sarti (20I0: 24) shows that the popularity of women as servants par excellence during the first half of the twentieth century proceeded more or less in step with the emergence of the models of the house- 
wife and the breadwinner as idealized female and male gender identities. This gender-typing made it difficult for male domestic workers to live up to ideals of hegemonic masculinity, but also made it difficult for them to access employment. Similarly, male migrant domestic workers in the Netherlands interviewed by van Walsum (20II: 153) all experienced difficulties finding employment, unless they had been brought into the business as their wives' assistants. Acceptance of their job is facilitated by their lack of alternatives in the labour market. For male migrants in Australia, Donaldson and Howson (2009: 210) point out that the assumption that their new job is "for the betterment of their families" is one way to justify and accept the change in their lives. The choosing of indignities and difficulties for the sake of the family gives meaning to the paid work that men undertake: "There is honour in self-sacrifice for the family" (Donaldson/ Howson 2009: 2I2). This is also reflected in findings on male domestic workers in Calcutta (Ray 2000: 713). Besides relating their work to the masculine quality of breadwinning, other ideal constructions of masculinity that male domestic workers associate with their work include responsible fatherhood and physical strength. This enables them to reduce the tensions they experience in doing 'women's work' and that are caused by their work in the private sphere.

In addition to the gender connotations of the occupation itself, its location in the private sphere is gendered, too. Professional work and politics are ascribed to the public sphere and they become a male domain, while reproductive labour in the private sphere is classified as female (Lutz 2002: 96). Men involved in migrant domestic work challenge this gendered divide. It is also the location of their workplace in the private sphere that raises the issue of masculinity for domestic workers, rather than their work alone.

Race is another social division that has been shown to be an important aspect of the production of domestic workers' identity. Nakano Glenn (1992) demonstrates for several regions of the United States that, "despite the large-scale historical transformation of paid reproductive labour from a model of 'servitude' to one of 'service work', the relegation of the dirty work to racial-ethnic women has remained remarkably consistent" (Duffy 2007: 316). Bartolomei (2010: 99) describes the complex intersections between gender and race in the employer-employee relationship. A Burkinabé male domestic worker she interviewed found it very challenging to work for a female black employer as "to obey a woman can be re- ally degrading for a black man". This challenge is absent when working for white people from whom he is culturally distant. The advantages of the invisibility of one's identity, in that it helps to avoid humiliation, is expressed by a male domestic worker who comes from a very respected family: "I prefer to work for white people who know neither my past nor my family".

The push towards racialized occupational niches in the host country's labour market, such as domestic work, for many migrant workers, male as well as female, entails the experience of deskilling when they take up work below their professional qualification and previous experience. Notions of work and occupation are critically important in the construction of gender identities and, given men's dominant perception as breadwinners, especially of hegemonic masculinities (Datta/Mcllwaine/Herbert/Evans/May/Wills 2009: 865; Lupton 2000: S34). Donaldson/Howson (2009: 2II) point out that, as a result, performing work beneath their skill levels has a significant effect on migrants' sense of manhood. In addition, deskilling has negative material consequences, given the precarious and badly paid nature of the jobs open to migrants in rich countries. For these reasons, their ability to effectively perform their role as their families' breadwinner is often deeply compromised.

\subsection{Contextualising Migrant Domestic Workers' Experiences in the Netherlands}

Migrant domestic workers to the Netherlands enter a country with a long history of immigration (van den Bergh 2006: 5). The first-generation foreign population of the Netherlands totals about I.7 million, about a tenth of the Dutch population (Statistics Netherlands 20II). In 20IO, the total population of migrants from the Philippines was 19,658, of whom an estimated I,200 had irregular status (Commission on Filipino Overseas 20I0). In recent years, the country has transformed its migration regime from generous to more restrictive policies (van den Bergh 2006: 5). The question of migrants' integration into Dutch society had been for a long time easily dismissed, based on the belief that the Netherlands offered a successful model of 'multiculturalism' and 'tolerance', where racism and ethnic discrimination did not exist. Today, however, the tolerance that Dutch people considered a positive quality inherited from their past seems to stand on shaky ground (Marchetti 20IO: 55). Based on, amongst other reasons, European Union direc- 
tives (Merlino/Parkin 20II: 7), the 20I0-I2 Rutte cabinet intended to make irregular stay in the country a criminal offence, an initiative that has polarized the Dutch society.

Many people who participate in the paid labour market in the Netherlands employ domestic workers in their houses. The comparatively high labour market participation of Dutch women since the early I970s is an important determining factor here, even if it has been accompanied by a high ratio of part-time working (de Ruijter/van der Lippe 2009: IO-II). In 2004, this resulted in I.2 million ${ }^{9}$ Dutch households hiring domestic workers (Nes/van Gravesteijn-Ligthelm/van den Boom 2004: v). Especially in the larger Dutch cities, workers providing domestic services are almost all migrants, many of them with irregular immigration status (van Walsum 20II: I43). Despite the sizeable demand, domestic work has not provided a valid entry route to the Netherlands for international migrants (Botman 20II: 55; Lutz 2002: 93). For migrants with irregular status, the location of the occupation in the private sphere may offer a distinct advantage in terms of avoiding state surveillance (Kilkey 20IO: I33), a logic that has been supported for the Netherlands (van der Leun/Kloosterman 2006: 66-67; van Walsum 20II: 155 ). Yet the private location of their work does not only offer refuge, but also presents risks. Live-in migrants in the Netherlands - even when their status is regular - have been identified as the category of domestic workers most likely to be exploited (van Walsum 20II: 158).

For 2009, the number of migrants with irregular status residing in the Netherlands was estimated at a little less than I00,000 (van der Heijden/Cruyff/van Gils 20II: I6). They cannot contribute to the social security system because of their lack of a 'citizen service number' and their lack of a work permit. As a result, they are unable to legally access unemployment benefits, pensions, or health insurance (Abvakabo FNV 2008). Access to other basic necessities, such as decent housing and fair pay, are also affected. Moreover, trivial actions like boarding a tram or sending money home are associated with a high degree of anxiety giving that contact with the police or other controlling authorities can result in detention and deportation (van Walsum 20II: 154).

In this context of great vulnerability, this study investigates the question of how Filipina/o domestic

9 This figure excludes the demand for domestic services related to childcare. It represented another 683,000 households. workers with irregular immigration status in the Netherlands balance their gender identity with their occupation at the intersection of other, often marginalising, social divisions.

\subsection{Research Methodology}

In order to answer this question, empirical data were generated through semi-structured interviews and (participant) observation. The interviews focused on respondents' work experience, gender roles, and experiences as migrants with irregular status. All interviewees were domestic workers ${ }^{10}$ with irregular immigration status ${ }^{11}$ from the Philippines. Seven men and five women, aged between 38 and 58 years, were interviewed during the period of July to September 20 II. All respondents entered the Netherlands legally, i.e. equipped with valid work permits and/or tourist visas. Their employers included people of various nationalities who worked in different sectors of the Dutch economy, but mainly in government or diplomatic services. Snowball sampling was employed due to the respondents' irregular immigration status. It prevented them from easily disclosing their identity and from confidently trusting outsiders. Potential interviewees were therefore first approached through a gatekeeper. Another reason for snowballing was that there was no legal documentation which could serve as a sampling frame. Selecting respondents this way had as a drawback that the homogeneity of interviewees' backgrounds increased. As a result, interviewees were likely to be Catholic, married, recent migrants, from Manila, and relatively of the same age. Respondents' names were changed to ensure that they cannot be identified.

The following two sections are organized around the narratives of seven of the twelve informants who agreed for their interviews to be recorded. They included five men (Angelo, Marco, Micki, Rido, and Silvianos) and two women (Marie and Sifora). While not referred to directly, the five unrecorded interviews contributed significantly to our understanding.

10 Some respondents occasionally work in other types of jobs, such as construction, catering, or as an electrician. 11 One respondent, Rido, obtained a work permit shortly before the interview. 
Table 6.1: Profiles of selected respondents. Source: Compiled by the authors.

\begin{tabular}{|c|c|c|c|c|c|c|}
\hline Name $^{a)}$ & Age & Sex & Marital status & $\begin{array}{c}\text { Year of entry } \\
\text { to the NL }\end{array}$ & Type of visa & Previous occupation \\
\hline Angelo & 54 & male & married & 2006 & contract & business \\
\hline Marco & 43 & male & married & 2008 & tourist & security guard \\
\hline Marie & 39 & female & single & 2004 & tourist & unemployed \\
\hline Micki & 38 & male & married & 2004 & contract & electrician \\
\hline Rido & 46 & male & separated & 2008 & contract & cook \\
\hline Sifora & 46 & female & married & 2008 & tourist & business \\
\hline Silvianos & 46 & male & married & 2009 & tourist & college instructor \\
\hline
\end{tabular}

a) Names are changed in order to protect the respondents' identities.

\subsection{Balancing Migrant Domestic Work with Gender Identity}

This section focuses on how Filipino male domestic workers in the Netherlands reconcile their sense of masculinity with doing work that is widely perceived as feminine. It contrasts this balancing act with the experience of female colleagues.

Silvianos works six to twelve hours a day as a parttime domestic worker. He visits the households of his employers in The Hague, earning ten euros per hour, including five euros transport costs. His brother, who also works as a domestic worker, motivated him to come to the Netherlands. Silvianos explained that his brother's income as a domestic worker in the Netherlands was three times higher than his former salary as a college instructor in the Philippines. For him, this was a convincing reason to decide to overstay the duration of his tourist visa and to assume irregular immigration status after he had entered the Netherlands in November 2009. He thought that it was a good opportunity to earn more money so that he could invest in his family's future:

I could not save money with what I have been receiving in the Philippines, my brother bought a house [in the Philippines] in five years' time by doing domestic work here in the Netherlands (Silvianos).

According to him, in the community he had lived in and in Philippine society more generally, a man is responsible for generating income and covering the family's expenses, mirroring the features of hegemonic masculinity sketched above. The wife, in contrast, is responsible for the domestic chores and takes care of the children. The husband works outside, while the wife works in the private sphere. Silvianos saw the man as the one who steers the boat and takes the final decision in the family. The rigidity of these social expectations became clear when he noted that some unemployed men who stay back in the Philippines and take care of their own households while their wives work abroad were perceived "as isolated pieces" and as "something not good to people's opinion". He viewed the resulting financial incapability and unemployment as 'unmanly'. This mirrors findings from other studies of male migrants' gender identities (e.g. Donaldson/Howson 2009: 2II), in which incapability to fulfil the role of the provider in addition to doing a woman's work inside the household were considered aspects of failed masculinities.

Silvianos explained that he sends money to the Philippines every weekend in order to manage the family's budget and to live up to his family's expectations of him as a man. Fulfilling the role of the provider also legitimizes his role in taking relevant decisions. Information and communication technologies aid migrants like Silvianos to bridge the distance between them and their families in order to be involved in day-to-day family decisions. Taken together, being provider for and decision-maker in his family form crucial aspects of his masculine identity. However, it is his work in other people's households-something he earlier referred to as 'women's work' and as something that might diminish his manhood-that enables him to satisfy these expectations. Hence, paradoxically, he fulfils his masculine role of breadwinner by accepting jobs below the social status he used to have in his home country and that are associated with demeaning male femininities.

Angelo, a 54-year-old father of four children, came to the Netherlands with his wife to work as a butler. His sister-in-law who worked in a diplomat's residence recommended him. When their third employer treated them very unfairly, demanding long working 
hours for low pay, this affected the couple's physical and mental health. They decided to leave the employer's residence and assumed irregular immigration status. Asked whether he liked his job, Angelo responded:

I like it because I do not have choice. This is the only way I can have money to send to my children (Angelo).

For the same reason, he accepted unpaid overtime:

I do things for the sake of my children to keep my job, so, I do not mind or it does not matter how long I work (Angelo).

In the Philippines, he explained, even though he had a restaurant, he was not generating much income. Referring to that time, he noted:

You can buy food, dress. If you want to buy something else, it is hard. [...] If you have two sons in college, you cannot afford it, if I were in the Philippines (Angelo).

While his irregular immigration status limited his opportunities in the Dutch labour market to domestic work, this job enabled Angelo to send remittances and, in this way, play his manly role as a father.

In line with hegemonic femininities in the Philippines, the female domestic workers interviewed emphasized their roles as mothers and the related ideal of care-taking. They discursively reproduced this ideal by explaining that they are not happy about leaving at home their husbands, who are now responsible for taking care of their children. Forty-six-year-old Sifora was one of the women interviewed. Invited by a friend, she came to the Netherlands for the second time in 2008. After her one-month tourist visa expired, she became a resident with irregular immigration status and started to work in domestic service. She now works eight to ten hours a day with different employers. Sifora justified her decision to migrate as follows:

I came here for work and this does not mean I want to leave my family. It is because I need to help my unemployed husband. And at this time in the Philippines, we cannot handle life, everything is becoming expensive. So, I work here all days of the week except Sunday and I send my family money every month. Sunday is my day off and I spend the whole day talking with my children and the husband through Skype. My husband is a good person; he takes care of my children very well (Sifora).

As Angelo and Silvianos, Sifora migrated for economic reasons. As if to justify her husband's resulting involvement in housework, she made it explicit that, in their own household, they do not have a live-in domestic worker except someone who does the laundry and irons it. Sifora pays the bills, school fees, and all other expenses of her household in the Philippines. While, in actual terms, she is the family's provider, in the narration of her role, she carefully avoided defining herself as breadwinner. Her image of her role in the family that she narrated during the interview is merely supportive. It appears that this depiction as secondary income-earner and primary carer is congruent with hegemonic femininity in the Philippines. She expressed the responsibility for the care of her children by pointing out that she sacrifices her whole day off Skyping with her family as one way of bridging the spatial distance. In line with the feminine caring ideal, Sifora relates to her children as 'my' rather than 'our' children, even when talking about her husband's care for them. The societal belittling of housework reflected in Angelo's views is echoed in her way of describing her husband. Specifically, she relates to him as 'helpful', while he is actually running the household and taking care of their children. Her narration exemplifies women's co-responsibility in reproducing gender hierarchies amongst men (Connell/Messerschmidt 2005: 848), in a similar way to the Filipina migrants who mock their 'domesticated' husbands as 'houseband' or 'huswife' in Margold (1995, quoted in Lan 2003: 193). At the same time, Sifora seemed to protect her husband's image from being damaged by his (un)employment status. By acknowledging him as being 'helpful' and a 'good person', she defended his masculinity, countering prevailing social perceptions about 'domesticated' husbands. The fact that she points out the lack of a domestic worker in their home is probably intended to signal economic necessity. It implies a reference to intersections between gender and class, similar to the class-specific masculinity ideals described in Gutmann (1996, quoted in Schippers 2007: 97) that may reduce the damage housework does to her husband's conformity with hegemonic masculinity: because Sifora and her family's economic situation does not allow them to hire a domestic worker, her husband's involvement in housework and care is less degrading.

The way Sifora sees herself and her husband reflects ambiguity. On the one hand, the emphasis she puts on her husband's support in her household back in the Philippines helps to justify her own decision to migrate for work, hence leaving behind her responsibilities as homemaker and primary carer for him to take over. On the other hand, by praising his loyalty, she apparently attempts to compensate for the degrading effect of housework on her husband's masculinity. The stigma of the male femininity he has assumed may indirectly affect her social status due to 
the relational nature of hegemonic gender identities. Yet his work in their household makes him a 'good person', not a 'good man', possibly reflecting Sifora's internalization of masculine ideals and her implicit acknowledgement of the symbolic emasculation he experiences. These observations indicate that when lived experiences deviate from societal scripts, respondents seem uneasy to accept these incongruences. The discursive portrayal of her own, and her husband's, performance of gender is a way to bring a reality that deviates from accepted standards closer to societal ideals.

Another male respondent, Micki, a 38-year-old father of four, initially worked as a contract worker in a diplomat's residence. He lost his work permit when he left that employer because of the exploitative conditions he experienced in live-in domestic service. Micki explained that working as an electrician or cook, occupations that he refers to as 'good jobs' in contrast to domestic work, is what he likes to do. However, his irregular status prevented him from finding such work. He works nine to ten hours a day as a domestic worker. He found domestic service with a female employer a very difficult situation. When his boss was present he felt shy about cleaning the house:

You see, the woman is sitting there and I clean the house [laughs]. I was shy! How can a man clean? (Micki).

He added that, in that situation, he was hardly able to move, and, as a result, unable to clean during the given time. According to his own standards, by performing the feminine occupation of a domestic worker, he had ventured into what Schippers (2007: 96) denoted by male femininities, a stigmatising gender identity. The visibility of his work in the private sphere to his female employer augmented the humiliation as, paralleling the incident narrated in Bartolomei (20I0: 99), obeying a female employer turns conventional gender hierarchies upside down. Last but not least, the paralysis he experienced as a result also had financial implications as he could not finish his work on time. This possibly threatened the main justification for accepting the degrading occupation abroad, namely, to play his breadwinning role in a more financially successful manner. He expressed this justification, centring on his role as provider for his children, very clearly:

I do not want them to leave their country for work like me. I am sacrificing for them, I do not want my son or daughter to work in another family, I am doing it for them (Micki).
Similar to the experiences described by Ray (2000), he described his migration as a sacrifice for the sake of his family. Endurance of the difficulties associated with his situation as a migrant domestic worker with irregular status, such as the degrading entry into a feminized occupation, were depicted as part of that sacrifice and hence made acceptable. The heroism of this sacrifice probably enabled him to recover some of the masculinity threatened by the shift to a feminine occupation and the humiliation of serving a female employer.

In sum, this section has investigated how Filipina/ o migrants with irregular status in the Netherlands balance their gender identities with doing domestic work in an occupation widely perceived as 'feminine'. Based on earlier studies, it was assumed that this poses a challenge to male migrant workers' sense of masculinity in particular. The results reported and discussed above have shown that migrant domestic workers' constructions of their gender identity oscillate between their occupation threatening the expectations associated with their gender roles and contributing to fulfilling these expectations. Male and female respondents' respective ideals of masculinity and femininity are surprisingly homogeneous, enabling us to speak of hegemonic masculinities centring on heteronormative practices of breadwinning and fatherhood as provisioning and hegemonic femininities rooted in caring.

The associated normative expectations are challenging both for men and women. While women perceive their decision to leave their children as a possible betrayal of their role of care-taker, without seeing domestic work as a challenge to their feminine identity, men perceive the female-typed occupation as a threat to their sense of masculinity. Hence, for women it is their migratory status which is endangering the fulfilment of localized reproductive responsibilities. For men, in contrast, it is their employment in female-typed domestic work and, thus, the stigmatising male femininity that characterizes it that is experienced as a threat.

Filipina/o migrant domestic workers in the Netherlands have developed different strategies, actual and discursive, to balance these risks. Sending remittances to their families in the Philippines is the main actual strategy for successful performance of their gender roles. While materially identical, in an effort to discursively bridge the gap between their lived lives and ideal gender identities, the money transfer is presented as breadwinning by migrant men and constructed as mere support by women, enabling them to 
care for their children. Intensive communication with the children via modern technology is another way of bridging the space. This enables Filipina migrants to fulfil their motherly role, while their male colleagues underline their significance for their involvement in family decision-making. For female and male respondents, speaking about their livelihood as a sacrifice for their children's/family's sake is another way of compensating a threatened sense of gender identity. While studies on Filipinas' labour migration have underlined the offering aspect of their mobility as "martyr mothers, dutiful daughters or sacrificial sisters" (Asis/ Huang/Yeoh 2004: 200; see also Chang/Ling 2000: 39; Lan 2003: 196; Parreñas 2005: 332), Filipino migrant domestic workers' voices illustrate that "contrary to discourses of spousal/family abandonment, men often migrate in order to support their families, and particularly to afford their children more opportunities than they themselves had" (Datta/Mcllwaine/ Herbert/Evans/May/Wills 2009: 856). While also involving emotional attachment, fatherhood is largely understood in terms of material provisioning. This justifies men's migration and the sacrifice of entering a feminized occupation.

The narrations of Filipina/o domestic workers in the Netherlands highlight the ways in which gender hierarchies are reproduced in discourse. Rooted in their notions of valued gender identities, the lack of recognition of feminine-typed domestic work is exemplified and corroborated in their statements regarding what can be considered 'good' work (not domestic work, in Micki's opinion) and regarding who is a 'good' person (Sifora's husband's, despite his engagement in domestic work). Paradoxically, this way the respondents themselves contribute to reproduction of the symbolic and material injustices that migrant domestic workers suffer from.

\subsection{Domestic Work at the Intersection of Class, Race, and Gender}

While interactions between the construction of domestic workers' gender identities and other social divisions have been identified in passing in the previous section, this section focuses on them.

Respondents pointed out that, in the Philippines, domestic work is performed by the poor, who are often rural migrants (see also Lan 2003: 194). Silvianos, a former college instructor himself, specified that people with little or no formal education take up such low-status jobs. Therefore, the experience of deskilling that resulted from taking up domestic work as an occupation is a matter of shame for him:

I ask myself: Do I deserve this? (Silvianos).

As in Bartolomei (2010: 99), making his background and, hence, the loss of social status invisible is a way of reducing the associated sense of humiliation:

Here, I am working domestic work around people who do not know my background, and this makes it a little easier. But, of course, in the Philippines, people know you well; you live and work around relatives and friends. And at this time I avoid telling my family, relatives and friends about my current work, as they could say something nasty comparing to my level of education, and my previous work as college instructor (Silvianos).

By moving to the Netherlands and taking up domestic work, Silvianos changed his class position from a salaried employee to an informal worker. The low social status of domestic work carries the connotation of poor levels of education. Silvianos' painful experience of deskilling contrasts with his simultaneous discovery that domestic work actually requires more skills than anticipated. He had thought domestic work was easy work, but realized its difficulty later:

... you need to know the techniques and master which place to start first in the household (Silvianos).

Rido moved from the skilled occupation of cook to domestic work. His comments further underline that this experience of declassing is difficult to accept. $\mathrm{He}$ told his family and friends that he is not a cook any more. Like Angelo, he justified this by explaining that, as a migrant with irregular status, he could not find any other job apart from domestic work:

They said it is okay, as long as you earn money [laughs] (Rido).

But he is disappointed with himself:

Yeah, I am angry at myself, I am domestic worker, I clean someone's house. Before, for twenty-five years, I have been a respected cook, cooking in big hotels and restaurants, I was a cook (Rido).

Besides the divergent skill and class connotations of his previous and current job, the location of his work has a role to play in how he perceived himself through the eyes of generalized others. The esteem associated with public places, such as hotels and restaurants, further contrasts with the invisibility and gender connotations of his current workplace in the private sphere. He occasionally works in the construction sector, taking on tasks like painting. This is work more in line with his notion of a masculine identity: 
I feel easy doing painting, because painting is men work. You see, I do it for the money in domestic work, I do not know how to do it (Rido).

More drastically, he stated:

... if I could be able to survive, I better choose to be unemployed than shifting from a cook to a domestic helper (Rido).

Keeping Silvianos' evaluation of unemployment as unmanly in mind, this statement is surprising. Possibly more than an actual preference, it was used as a rhetoric device emphasising - once again - the threat of male femininities that work in domestic service holds for Filipino men's sense of dignity. They are probably rooted in the perception that unemployment would preserve the higher class position - alongside the conformity with hegemonic masculinity - of his previous occupation.

Interestingly, Angelo and Micki mention that, in the Philippines, both women and men work as domestic workers, which contrasts with Micki's earlier exclamation: "How can a man clean?" Possibly, in Filipino society, their ranking above poor workers in domestic service explains this contradiction. Domestic work would be considered unmanly for middle-class males, but acceptable - or, at least, common - for working-class men. Such intersections between gender identity and class have also been identified in Sarti's (20IO) study on migrant domestic work in Italy. Despite the fact that the father of one of her respondents was a domestic worker back in the Philippines, the respondent thought that domestic work is "really a female's job" (Sarti 20IO: 30). She points out that: "By ignoring or denying the existence of male domestics, they reveal that they share the idea that male domestic workers are not really men and support a conception of masculinity which backfires on them" (Sarti 20IO: 3I).

In contrast to the men interviewed, female respondents did not complain about their occupation or emphasized the compulsion to do domestic work due to their immigration status. This is despite the fact that, for example, for Sifora, too, entry into domestic work involved a process of deskilling and a loss of the societal prestige associated with her earlier job as a businesswoman. This acceptance is probably rooted in the perception of domestic work as an extension of 'natural' female skills and associated with the female-typed sphere of the private home, something that both female and male respondents had internalized. It led to a perceived challenge to male respondents' gender identities, but is in line with female migrant domestic workers' gendered role expectations.

The discussion of the respondents' narrations above has indicated already that the workplace of migrant domestic workers in the private home plays a significant yet ambiguous role. In contrast to their female colleagues, the classification of the private sphere as feminine poses a challenge to male domestic workers' gender identity. Besides this, the exploitative circumstances of live-in arrangements, in particular, threaten all domestic workers' material and physical security - so much so that some of them preferred the vulnerability of irregular immigration status to it. Yet at the same time the invisibility of these private places of work appears to offer protection from state surveillance, especially for workers with irregular immigration status, and makes their misrecognized work less visible.

Marco's experience sheds more light on the dynamics operating between migrant domestic workers' gender and their immigration status, as well as on the role of employers in reproducing these dynamics. Marco is a 43-year-old married father of three. Entering on a tourist visa and invited by his sister, he has stayed in the Netherlands as a domestic worker with irregular immigration status since 2008 . For six days a week, he works a minimum of six hours a day, generating daily earnings of around seventy euros. This enables him to remit 400-500 euros per month to his family in the Philippines. Like all male respondents, Marco explained that domestic work is something that he learned in the Netherlands. He, too, underlined the compulsion that brought him to this occupation. He felt he was obliged to learn any kind of job in order to earn money. The association of domestic work with the female gender not only poses a challenge to his masculinity, it also leads to gender-based discrimination in access to jobs in domestic service. Once, a Filipina friend who is likewise a domestic worker recommended him to a potential employer. When calling him,

... the employer was a bit surprised and asked me whether I am documented or not and I lied that I am documented (Marco).

The employer told him that he had to discuss the issue with his wife and would respond later. After a couple of days, the employer told him that his wife was looking for a girl. Marco was disappointed. He noted that:

Some employers like to hire female domestic workers. Because, they take domestic work as a kind of work that 
belongs to female only. And they think women only can do much better than men (Marco).

Apparently, because of the gender connotations of domestic work, being a male domestic worker signalled irregular immigration status to this potential employer. Only the compulsion of scarce labour market opportunities typical for workers with irregular status would bring a male migrant to apply for employment in domestic service. Through this process of screening based on normative assumptions regarding the gender and immigration status interactions in domestic work, employers, as actors in a more powerful position in the arena of domestic work, play their part in reproducing these very assumptions (Ray 2000: 695) and entrenching the notion that valued masculinities are associated with whiteness and the middle class.

Marie is a 39-year-old domestic worker who works for ten families in The Hague. She placed employers' negative attitude vis-à-vis male domestic workers in the context of sexuality:

I have heard from one of my employers that her friends recommended her a male domestic worker and she refused to hire. She [employer] said that she wants her daughter to wear freely at home and she does not want her daughter feel an outsider's man attention in her own house (Marie).

Marie heard similar concerns from other employers, especially in families with teenage daughters. Highlighting the intersection of gender with sexuality in the social construction of domestic work, hiring male domestic workers is seen as a potential sexual threat to women in a family. Marie added that she knows many male domestic workers who work as the assistants of female domestic workers and who split the money between them as a strategic reaction to employers' gender preferences (see also van Walsum 20II: I53). Particularly when women workers have long working hours, they 'subcontract' work to male domestic workers. They describe this collaboration as giving assistance to their Filipino menfolk in increasing their employment opportunities. By emphasizing their own supportive role and their male colleagues' breadwinning role, this practice might be placed in the context of women affirming both their own and their male colleagues' congruence with hegemonic gender identities.

Other than assumed in the images of the 'tolerant' Netherlands, migrant domestic workers' racial background as well as racialized ascriptions also influence their position in the labour market and their life more generally. Angelo realized that Europe is not the champion of non-discrimination:

... they look at us as nobody and as if we are nothing (Angelo).

He did not feel respected by his white employers:

Especially in the [diplomatic] residence, I do not think they have respect, because you are there and you are helping them (Angelo).

While he saw domestic work as the only way to find work as a migrant with irregular status, he concedes that even with a regular work permit, racial discrimination in the labour market persists:

They may give us lower jobs. Even the professionals, I don't think they are professionals here (Angelo).

Rido preferred to work with English speakers rather than with Dutch employers, as it was hard for him to communicate in Dutch. At the same time, he did not want to work with employers from the Philippines, despite the common language. They pay low wages and:

... I am not comfortable if my employer is Filipino (Rido).

Similarly to Bartolomei's findings (2010: 99), his preference indicates that the same racial background may also represent a disadvantage. This has both material and symbolic dimensions. Normative expectations and benchmarks may be shared, too, implying that the invisibility of his degrading work is made impossible. Not unimportantly, Filipina/o employers are able to consider the lower living costs and wage levels in their home country in comparison with the Netherlands, explaining the poor pay. Emotionally, the discrimination and marginalization that respondents experience on the basis of their race is counterbalanced by positive ascriptions. Micki pointed out that Filipina/o domestic workers are well paid compared to other nationals (see also ILO 20IO: 7; van Walsum 20II: I52-I53). He relates the better pay to perceptions of diligence in and commitment to their work:

And one employer said I like Filipino, they are hard workers, I was happy and my heart was beating fast. Because Filipino work hard they do not focus on hours, they only care about their work. And Filipinos are good workers, and trusted by their employers, trust me (Micki).

Van Walsum (20II: I52) comes to the more sobering conclusion that Filipina/o domestic workers' comparatively higher payment is related to their reputation as "ideal providers of care and household services", 
actively promoted by the Filipino government and commercial brokers (see Rodriguez 20IO).

This section has shown how the (re-)construction of domestic workers' gender identities is intersected with class, race, and immigration status. Overall, for the respondents, domestic work has the connotation of working-class status. This is difficult to separate from gender features of the occupation, though. The fact that it is largely women who perform domestic work implies a social construction of low skill content resulting in the perception that this work does not deserve high wages. All three factors together generate the class connotation that the male respondents, in particular, refer to and which they experience as a painful loss of social status compared to with their earlier occupations. To deal with this experience of declassing and the stigma of male femininities, male migrant domestic workers point to the actual, demanding skill requirements of their occupation, something that resonates with other research findings (Datta/McIlwaine/Herbert/Evans/May/Wills 2009: 865-866).

Furthermore, their irregular status sets limitations to their agency, especially their "fear to be caught one day" (Angelo) and the limited opportunities for accessing the legal labour market. Male respondents in particular saw their inability to obtain a work permit as the main cause for taking up domestic work as one of the lowest threshold occupations in the Dutch labour market, characterized by a lack of employment, income, and social security. Yet the irregularity of their immigration status intersects with the location of their work in an ambiguous manner. While their work in the private sphere can be seen as protective against threatening surveillance by public authorities, this invisibility also increases employers' power over domestic workers and makes them vulnerable to economic and physical exploitation.

With regard to the intersection between race, gender, and domestic work, migrants' Filipina/o background channels them into a narrow set of labour market options, with domestic work being dominant amongst these. Within this racialized niche, their nationality is associated with a very good reputation. Van Walsum (20II: 153) highlights possible pitfalls of this branding as 'ideal domestic workers', as it could also work against them if they acquire legal status.

The emerging theme of domestic work as 'help' and 'assistance' can be considered a focal point of respondents' constructions of their work. Sifora defended her decision to migrate by her obligation to 'help' her unemployed husband, who again is 'helpful' by taking over the housework back in the Philippines. Rido referred to himself as a 'domestic helper', something that he experienced as a downgrading from salaried professional to wage worker. While Marie confirmed female and male gender identities by declaring the subcontracting of domestic work to male colleagues as 'assistance', Angelo described the position in the racial hierarchy in which migrant domestic workers in the Netherlands are placed as 'helpers'. The ways in which these notions were used with reference to domestic work imply subordinated agency (see Lan 2003: 205, footnote 6) as well as gender, class, and racial hierarchies in which migrant domestic workers are located at the lowest rank.

\subsection{Conclusion}

The bulk of scholarly work on migrant domestic work concentrates on women. Our research, in contrast, has taken the finding that a significant and growing number of migrant men are taking on domestic work as its point of departure. From the perspective of hegemonic gender identities, we have shown that male migrant domestic workers, too, are subjected to gender injustice. The injustices they experience are rooted in the devaluation of everything coded as 'feminine' (Fraser 2007: 26), including their occupation. The resulting male femininities are threatening male domestic workers' sense of self-worth and their societal recognition. This misrecognition adds to the exploitative economic circumstances that both female and male migrant domestic workers experience and has negative repercussions on male migrants' access to employment. Ironically, migrant domestic workers themselves contribute to reproducing these symbolic and material injustices and hence consolidate them. By adopting hegemonic gender identities as their normative point of reference, both female and male migrants implicitly support domestic work's low societal status through their belittling of their 'feminine' and declassing occupation.

Migrant domestic workers' individual struggles to deal with these experiences of injustice are embedded in contestations over the role of reproduction in wider Dutch society. Women's improved access to paid employment, which has gone unmatched by men's involvement in housework, has been achieved at the expense of respect and reward for migrant domestic workers. Their vital role for Dutch society, filling the reproductive gap that has opened as a result of greater gender justice in the paid labour market, con- 
trasts starkly with the invisibility of their work in private homes, as well as with their marginal social and economic status. The forms of injustices that female and male migrant domestic workers face in a variety of ways entrench the symbolic and material divides between migrants and employers, as well as between migrants' home and host societies. While this has been pointed out in earlier studies, we bring to the fore how migrant domestic workers' efforts to adhere to hegemonic gender identities not only reproduce patriarchal gender relations amongst themselves, but also corroborate white privileges in productive and reproductive work.

Given the 'two faces' of gender justice that Fraser (2007: 26) identifies, redressing these injustices requires changes both in the economic structure and in the status order of contemporary society. In combining the demands for respect and for labour rights for domestic workers, this necessity is reflected in domestic workers' national (see for example FNV Bondgenoten 20II) and international campaigns (see for example IRENE/IUF 2008; IDWN no date) that have culminated in the ratification of the International Convention Concerning Decent Work for Domestic Workers by the International Labour Conference (ILC 20II) as an intermediate success. These labour movements have taken on a new terrain of struggle. Beyond the traditional focus on the material aspects of labour conditions, the new approach has taken workers' social status into account and has also led to a campaign for greater respect. Its emergence is probably related to an increasing awareness of the rise of precarious employment relations amongst trade unions. Precariousness, in turn, is often related to the low social status of the respective work. ${ }^{12}$ Importantly, these struggles have included changes in domestic workers' own mindsets, from seeing themselves as 'helpers' to emphasizing their dignity as workers.

While national and transnational labour movements for greater social justice for migrant domestic workers have been effective, they are probably not the most powerful actors in this arena. In many cases, national labour regulation continues to neglect the private home as a workplace (ILO 20IO; Simonovsky/ Luebker/Oelz 20II) due to gendered association of work and breadwinning with the public sphere. This chapter's intersectional analysis has shown how these legal frameworks are underpinned by social constructions of migrant domestic workers' location of work,

12 We are grateful to Freek Schiphorst for pointing this out. their subordinate gender identities, race, and immigration status, and how these interact to mute demands for respect and adequate reward. In order to redress this situation and to achieve parity of participation in the labour market, national governments have to abandon the androcentric assumption that industrial workplaces are the benchmark for labour regulation. Rather, they should strive to effectively cover all workers, independent of the location of their work, their gender, their race, or their immigration status, with the protection they deserve.

The transnational nature of the social and economic relations that this chapter has investigated is a reminder that the nation state is no longer the sole territorial unit within which justice is applied (see Fraser 2009). As the social movement for respect and rights for domestic workers has become transnational, adequate regulation to prevent abuses and fraudulent practices in recruitment, placement, and employment of migrant workers should be based on bilateral, regional, or multilateral agreements (see Article $15 \mathrm{~d}$ in the International Convention Concerning Decent Work for Domestic Workers, ILC 20II).

Hence, policymakers at the level of the European Union and the World Trade Organization, for example, should reconsider whether they want to submit tasks that are as crucial to societal reproduction as domestic work to restrictive migration management based on the arbitrary definition that domestic work does not require skills. A redefinition and relaxation here is likely to lead to both greater societal recognition for domestic work and a subsequent improvement of their material conditions of work. This would be in line with Fraser's conclusion (2007: 34) that: "Only an approach that redresses the cultural devaluation of the 'feminine' precisely within the economy (and elsewhere) can deliver serious redistribution and genuine recognition."

\section{References}

Abvakabo FNV (Algemene Bond van Ambtenaren, Katholieke Bond van Overheidspersoneel Federatie Nederlandse Vakbeweging) (Public Sector Trade Union); since I982 known as Abvakabo FNV, 2008: Your Rights as a Domestic Worker in a Private Household (Zoetermeer: Abvakabo FNV); at: <http://www.abvakabofnv.nl/PDF/ downloads/folder-rechten-als-huishoudelijke-hulp/ I93055/.pdf> (23 July 20I2).

Asis, Maruja Milagros B.; Huang, Shirlena; Yeoh, Brenda S.A., 2004: "When the Light of the Home is Abroad: Unskilled Female Migration and the Filipino Family", in: Singapore Journal of Tropical Geography, 25,2: 198-215. 
Bartolomei, Maria Rita, 20I0: "Migrant Male Domestic Workers in Comparative Perspective: Four Case Studies from Italy, India, Ivory Coast, and Congo", in: Men and Masculinities, I3,I: 87-IIO.

Botman, Sjoukje Johanna, 20II: Gewoon Schoonmaken: De Troebele Arbeidsrelaties in Betaald Huishoudelijk Werk (Amsterdam: University of Amsterdam).

Chang, Kimberly A.; Ling, L.H.M., 2000: "Globalization and its Intimate Other: Filipina Domestic Workers in Hong Kong”, in: Marchand, Marianne H.; Runyan, Anne Sisson (Eds.): Gender and Global Restructuring: Sightings, Sites and Resistances (London: Routledge): 27-43.

Commission on Filipino Overseas, 20IO: "Responding to the Challenges of Migration and Development: Stock Estimation of Overseas Filipinos" (December 20IO); at: <http://www.cfo.gov.ph/index.php?option=com_content \&view=article\&id=I340:stock-estimate-of-overseas-filipinos\&catid $=\mathrm{I} 34>$ (23 July 20I2).

Connell, R.W.; Messerschmidt, James W., 2005: "Hegemonic Masculinity”, in: Gender \& Society, 19,6: 829-859.

Datta, Kavita; McIlwaine, Cathy; Herbert, Joanna; Evans, Yara; May, Jon; Wills, Jane, 2009: "Men on the Move: Narratives of Migration and Work among Low-Paid Migrant Men in London”, in: Social \& Cultural Geography, Io,8: 853-873.

De Ruijter, Esther, 2004: "Trends in the Outsourcing of Domestic Work and Childcare in the Netherlands", in: Acta Sociologica, 47,3: 219-234.

De Ruijter, Esther; van der Lippe, Tanja, 2009: "Getting Outside Help", in: Journal of Family Issues, 30,1: 3-27.

Donaldson, Mike; Howson, Richard, 2009: "Men, Migration and Hegemonic Masculinity", in: Howson, Richard; Pease, Bob; Hibbins, Raymond; Donaldson, Mike (Eds): Migrant Men: Critical Studies of Masculinities and the Migration Experience (New York: Routledge): 2IO-2I8.

Duffy, Mignon, 2007: "Doing the Dirty Work", in: Gender \& Society, 21,3: 313-336.

FNV (Federatie Nederlandse Vakbeweging) Bondgenoten, Last updated 20II: "Schoon Genoeg!" (Vakbond van Schoonmakers/FNV Bondgenoten website), at: <http:/ /www.schoongenoeg.nu/afdeling/domestic-workers/> (23 July 20I2).

Fraser, Nancy, 2007: "Feminist Politics in the Age of Recognition: A Two-Dimensional Approach to Gender Justice”, in: Studies in Social Justice, I,I: 23-35.

Fraser, Nancy, 2009: "Who Counts? Dilemmas of Justice in a Postwestphalian World", in: Antipode, 4I,SI: 28I-297.

Gutmann, Matthew C., 1996: The Meanings of Macho: Being a Man in Mexico City (Berkeley: University of California Press).

Haile, Aster Georgo, 20II: Masculinity, Work and Rights through the Lens of Citizenship: Filipino Male Domestic Workers in the Netherlands. ISS MA Research Paper (The Hague: International Institute of Social Studies of Erasmus University Rotterdam (ISS)).
Herbert, Joanna, 2008: "Masculinity and Migration: Life Stories of East African Asian Men”, in: Ryan, Louise; Webster, Wendy (Eds): Gendering Migration: Masculinity, Femininity and Ethnicity in Post-War Britain (Burlington etc.: Ashgate Aldershot): 189-203.

Hochschild, Arlie Russell, 2000: "Global Care Chains and Emotional Surplus Value”, in: Hutton, Will; Giddens, Anthony (Eds): On the Edge: Living with Global Capitalism (London: Jonathan Cape): I30-I46.

IDWN (International Domestic Workers' Network): "International Domestic Workers' NetWork” (IDWN webpage); at: <http://www.idwn.info/> (23 July 20II).

ILC (International Labour Conference), 20II: "Text of the Convention Concerning Decent Work for Domestic Workers", International Labour Conference $100^{\text {th }}$ Session (Geneva: ILO); at: <http://www.ilo.org/wcmsp5/ groups/public/--ed_norm/--relconf/documents/ meetingdocument/wcms_I57836.pdf> (3 August 20I2).

ILO (International Labour Office), 20I0: Decent Work for Domestic Workers: Report IV (I). International Labour Conference $99^{\text {th }}$ Session (Geneva: ILO); at: <http:// www.ilo.org/wcmsp5/groups/public/@ed_norm/@relconf/documents/meetingdocument/wcms_I04700.pdf> (3 August 20I2).

IRENE (International Restructuring Education Network Europe) and IUF (International Union of Food, Agricultural, Hotel, Restaurant, Catering, Tobacco and Allied Workers' Associations), 2008: Respect and Rights: Protection for Domestic/Household Workers! (Tilburg: IRENE/IUF); at: <http://www.irene-network.nl/download/ResRights.pdf > (23 July 20I2).

Kilkey, Majella, 20Iо: "Men and Domestic Labor: A Missing Link in the Global Care Chain”, in: Men and Masculinities, I3,I: I26-I49.

King, Alison Jill, 2007: Domestic Service in Post-Apartheid South Africa: Deference and Disdain (Aldershot: Ashgate).

Koo, Eunjung, 20II: Exploring Variations in Identity Dynamics Among Migrant Domestic Workers in the Netherlands. ISS MA Research Paper (The Hague: International Institute of Social Studies (ISS) of Erasmus University Rotterdam).

Lan, Pei-Chia, 2003: "Maid Or Madam? Filipina Migrant Workers and the Continuity of Domestic Labor", in: Gender \& Society, 17,2: 187-208.

León, Margarita, 20I0: "Migration and Care Work in Spain: The Domestic Sector Revisited", in: Social Policy and Society, 9,3: 409-4I8.

Luebker, Malte; Simonovsky, Yamila; Oelz, Martin, 20II: Coverage of Domestic Workers by Key Working Conditions Laws. Domestic Work Policy Brief 5 (Geneva: ILO); at: 〈http://www.ilo.org/wcmsp5/groups/public/ --ed_protect/-protrav/-travail/documents/publication/wcms_I57509.pdf> (23 July 20I2).

Lupton, Ben, 2000: "Maintaining Masculinity: Men Who do 'Women's Work', in: British Journal of Management, II (Special Issue): 33-48. 
Lutz, Helma (Ed.), 2008: Migration and Domestic Work: A European Perspective on a Global Theme (Aldershot: Ashgate).

Lutz, Helma, 2002: "At Your Service Madam! The Globalization of Domestic Service”, Feminist Review, 70: 89I04.

Marchetti, Sabrina, 2005: We had Different Fortunes: Relationships between Filipina Domestic Workers and their Employers in Rome and in Amsterdam (MA Thesis, Utrecht: University of Utrecht); at: <http://igiturarchive.library.uu.nl/student-theses/2006-0324-0832I3/ RMA\%20thesis\%20Marchetti.pdf> (23 July 20I2).

Marchetti, Sabrina, 20I0: Paid Domestic Labour and Postcoloniality: Narratives of Eritrean and Afro-Surinamese Migrant Women (PhD thesis, Utrecht: University of Utrecht), at: <http://igitur-archive.library.uu.nl/dissertations/20I0-05I7-20023I/marchetti.pdf > (23 July 20I2).

Margold, Jane A., I995: "Narratives of Masculinity and Transnational Migration: Filipino Workers in the Middle East”, in: Ong, Aihwa; Peletz, Michael G. (Eds): Bewitching Women, Pious Men: Gender and Body Politics in South East Asia (Berkeley: University of California Press): 274-298.

Medina, Belen Tan-Gatue, 200I: The Filipino Family (Quezon City: University of the Philippines Press).

Merlino, Massimo; Parkin, Joanna, 20II: Irregular Migration in Europe: EU Policies and the Fundamental Rights Gap (Brussels: Centre for European Policy Studies (CEPS)).

Moya, Jose C., 2007: "Domestic Service in a Global Perspective: Gender, Migration, and Ethnic Niches”, in: Journal of Ethnic and Migration Studies, 33,4: 559-579.

Nakano Glenn, Evelyn, 1992: "From Servitude to Service Work: Historical Continuities in the Racial Division of Paid Reproductive Labor”, in: Signs, I8,I: I-43.

Nes, Peter; van Gravesteijn-Ligthelm, José; van den Boom, Linda, 2004: De markt voor persoonlijke dienstverlening (Rotterdam: Stichting Economisch Onderzoek (SEOR), Faculty of Economics, Erasmus University Rotterdam Erasmus; at: <http://docs.szw.nl/pdf/I29/2004/ I29_2004_3_683I.pdf> (23 July 20I2).

Oelz, Martin, 20II: Remuneration in Domestic Work. Domestic Work Policy Brief I (Geneva: ILO); at: <http://www.ilo.org/wcmsp5/groups/public/ed_protect/--protrav/--travail/documents/publication/ wcms_I55654.pdf> (23 July 20I2).

Parreñas, Rhacel, 2005: "Long Distance Intimacy: Class, Gender and Intergenerational Relations between Mothers and Children in Filipino Transnational Families", in: Journal of Transnational Affairs, 5,4: 3I7-336.

Ray, Raka, 2000: "Masculinity, Femininity, and Servitude: Domestic Workers in Calcutta in the Late Twentieth Century”, in: Feminist Studies, 26,3: 69I-718.
Rodriguez, Robyn Magalit, 20I0: Migrants for Export: How the Philippine State Brokers Labor to the World (Minneapolis, MN: University of Minnesota Press).

Sarti, Raffaella, 2006: "Domestic Service: Past and Present in Southern and Northern Europe", in: Gender \& History, I8,2: 222-245.

Sarti, Raffaella, 20I0: "Fighting for Masculinity: Male Domestic Workers, Gender, and Migration in Italy from the Late Nineteenth Century to the Present”, in: Men and Masculinities, I3,I: I6-43.

Schippers, Mimi, 2007: "Recovering the Feminine Other: Masculinity, Femininity, and Gender Hegemony", in: Theory and Society, 36,I: 85-102.

Simonovsky, Yamila; Luebker, Malte, 20II: Global and Regional Estimates on Domestic Workers. Domestic Work Policy Brief 4 (Geneva: ILO); at: <http:// www. ilo.org/wcmsp5/groups/public/_ed_protect/-protrav/--travail/documents/publication/wcms_I5595I. pdf> (23 July 2OI2).

Statistics Netherlands, 20II: "Population; Key Figures" (The Hague: Statistics Netherlands); at: <http://statline.cbs.nl/StatWeb/publication/?VW=T\&DM=SLEN\& $\mathrm{PA}=37296 \mathrm{eng} \& \mathrm{DI}=\mathrm{a} \& \mathrm{D} 2=0, \mathrm{IO}, 20,30,40,58-59 \& \mathrm{HD}=0903$ O2- $\mathrm{IO} 45 \& \mathrm{LA}=\mathrm{EN} \& H D R=\mathrm{GI} \& S T B=\mathrm{T}>$ (23 July 20I2).

UNESCO (United Nations Educational, Scientific and Cultural Organization), 2008: People on the Move. Handbook on Selected Terms and Concepts. Version I.০, at: <http://unesdoc.unesco.org/images/oor6/oor636/ı6 362Ie. pdf> (3 September 20I2).

Van den Bergh, Hiske, 2006: Causes of Different Reactions of EU Countries to Illegal Migration. Summary Research Report (Utrecht: Pharos).

Van der Heijden, Peter G.M.; Cruyff, Maarten; van Gils, Ger H.C., 20II: Schatting Illegaal in Nederland Verblijvende Vreemdelingen in 2009 (Utrecht: Universiteit Utrecht).

Van der Leun, Joanne; Kloosterman, Robert, 2006: "Going Underground: Immigration Policy Changes and Shifts in Modes of Provision of Undocumented Immigrants in the Netherlands", in: Tijdschrift voor Economische en Sociale Geografie, 97,I: 59-68.

Van Dijken, Wieke, 2002: Slaves Or Militants: A Study on Identity Formation Processes of Migrant Domestic Workers in the Netherlands (MA thesis, Amsterdam: Vrije Universiteit).

Van Walsum, Sarah, 20II: "Regulating Migrant Domestic Work in the Netherlands: Opportunities and Pitfalls", in: Canadian Journal of Women and the Law/Revue Femmes et Droit, 23,I: I4I-I65.

Yeates, Nicola, 2004: "Global Care Chains", in: International Feminist Journal of Politics, 6,3: 369-39I.

Open Access. This chapter is distributed under the terms of the Creative Commons Attribution Non-commercial License, which permits any noncommercial use, distribution, and reproduction in any medium, provided the original author(s) and source are credited. 